Article

\title{
Black Religion and Black Power: The Nation of Islam's Internationalism
}

\author{
Bayyinah S. Jeffries $1 D$ \\ Department of African American Studies, Ohio University, Athens, OH 45701, USA; jeffrieb@ohio.edu
}

Received: 1 April 2019; Accepted: 24 June 2019; Published: 29 June 2019

check for updates

\begin{abstract}
The Nation of Islam's influence has extended beyond the United States. This Black American Muslim movement has used the intersection of race and religion to construct a blueprint of liberation that has bonded people of African descent throughout the Diaspora. Their transnational dimensions and ideas of freedom, justice and equality have worked to challenge global white imperialism and white supremacy throughout the 20th century and beyond.
\end{abstract}

Keywords: internationalism; Islam; Nation of Islam; Black Muslim

"Islam will give you true brothers and sisters the world over". (Muhammad 1965, p. 85)

“We are not an organization; we are a world". (Muhammad 1965, p. 322)

"... the darkest Arabs I have yet seen are right here in the Arab peninsular. Most of these people would be right at home in Harlem. And all of them refer warmly to our people in America as their 'brothers of color'"'. (X 1959, p. C1)

Since the period of African enslavement and European colonialization, Black people's experiences have overlapped in at least three key areas: (1) the exploitation of labor or economic deprivation; (2) religious interference; and (3) educational indoctrination. On the continent of Africa, people suffered torture, abuse, complete disruption and trauma from European intrusion. Outside of Africa, Black people have grappled with a system of racial oppression that criminalized, dehumanized and at times completely blocked any path to socioeconomic advancement, including miseducation, chronic unemployment, underemployment, mass incarceration and indiscriminate violence against black bodies. To combat these concerns, Black people founded organizations, mutual aid societies, schools, churches and other institutions. But the great majority of these initiatives increased the degree to which Black people relied upon white benevolence. It was not until Marcus Garvey founded the United States (U.S.) branch of the Universal Negro Improvement Association (UNIA) in 1916 that Black people in the United States found a way to socioeconomically move themselves away from their former oppressors, at least to a degree. Garvey's movement provided a glimpse of what "Black Power" could do. More importantly, his black enterprises represented a strong symbol of black self-determination. The Nation of Islam (NOI or Nation) not only filled the void left by Garvey as a model of black power but the Nation helped to advance Garvey's mission of black self-determination. More importantly, like Garvey, the Nation shared an international vision free from white interference and control.

Of all the tools white people have wielded in an effort to undermine Black community efforts towards political and financial autonomy, religion has been one of the most powerful. It is through religion that white supremacy gained significance throughout the African Diaspora. Christianity provided justification for the exploitation of black bodies during enslavement and the subsequent colonization of Africa. While it is true that slavery existed well before the human trafficking of black bodies by Europeans and their subsequent colonization of most of Africa, it was by no means the chattel slavery that followed under the cloak of Christianity. 
As the oldest grassroots Black Muslim movement in America, the Nation of Islam created a theology and praxis of liberation that was fashioned in response to the Western interpretation of Christianity intermingled with White supremacist ideology. This Black Muslim movement, the NOI, sought to expose and undermine the link between white supremacy and Christianity, both of which served to obstruct black self-determination throughout the African Diaspora from their perspective. The Nation also envisioned a religion that was steeped in the unique experiences of Black people and provided Black people with a weapon that was strong enough to challenge this European-centered Christianity. It also offered a powerful model of black power and provided them with the authority to fashion God in their own image. As a result, Black people within the Nation exercised power over themselves and their communities in terms of their religious practices and doctrine. This essay argues that the Nation of Islam's influence in terms of its theology, programs and socioeconomic ideas had international significance. Through the intersection of race and religion, the Nation successfully provided a plan that not only challenged global white supremacy but also offered a program of self-determination for people of African descent who resided wherever the legacy of enslavement, colonialism and Western imperialism existed.

\section{Brief History}

The Nation of Islam was founded by W.D. Farad Muhammad in Detroit Michigan in 1930. Elijah Muhammad, Farad's student, subsequently led the organization was from 1932 to 1975. When Elijah Muhammad assumed leadership over the NOI in 1932, the organization only had a small following in Detroit. A year later Muhammad established another temple in Chicago, IL, which became the NOI's headquarters. Between 1930 and 1936, he formed chapters in Milwaukee, Washington, DC and Cincinnati. Though scholars generally regard the NOI as a northern movement (Essien-Udom 1971; Joseph 2006; Lincoln 1961; Ogbar 2005), their influence also reached deep into the southern corners of the U.S., including Georgia, New Orleans and Texas and westward to places like Oakland, CA. By the mid-1960s, the original Nation of Islam also gained traction overseas, including in Bermuda, Jamaica, Honduras and eventually even Europe. After Muhammad's death in 1975, the Nation of Islam continued under two separate groups: the Community of Al Islam in the West or The American Muslim Mission, which Elijah Muhammad's son, Imam W.D. Mohammed, spearheaded; and, The Nation of Islam, which the former NOI national spokesman Minister Louis Farrakhan led. Though they ultimately took separate paths, both groups remained committed to a transnational vision. However, it was Farrakhan's group who maintained a black power agenda.

Prior to 1975, the Nation of Islam operated on two fronts. On the one hand, the Nation sought to align itself with the liberation movements of people of African and Asian descent. On the other side, the Nation allied itself with the global Muslim community. In both cases, Black American Muslims shared a similar history of resistance and oppression that linked directly to Christian imperialism and white supremacy. Upon Elijah Muhammad's death, Farrakhan and the newly revived Nation of Islam continued to promote this double identity of being both black and Muslim throughout the late 1970s and up until today. Under W.D. Mohammed, who assumed control after the passing of his father in 1975, the group, the American Muslim Mission, moved toward aligning itself with a more traditional practice of Islam. Consequently, the group's longtime commitment to black nationalism and weighing in on American racial politics mostly faded and conventional Islamic and American cultural acceptance and assimilation assumed priority.

In this work, the Nation of Islam includes the original Nation of Islam and its restoration under Minister Farrakhan. Both of these Nations demonstrated a commitment to a global black movement grounded both in black self-determination and the Islamic principles of freedom, justice and equality.

\section{NOI's International Aspirations and Applications}

The Nation of Islam developed programs grounded in "Black Power" principles desirable to people of African descent in the United States and beyond its borders. Nearly every aspect of its agenda 
attempted to address the significant disruption and damage caused by chattel slavery and its legacy. For instance, to combat the eradication of black religiosity initially practiced by enslaved Africans, the NOI introduced, or, in some cases reintroduced Islam, a religion that had historically challenged Western religious ideas. In addition, to address efforts to obliterate other aspects of African culture, such as names, dress, food, education, socialization and marriage practices, the NOI constructed a new way of life. As black self-determination remained its primary objective, the NOI focused on designing unique clothing and uniforms, introducing bean pies and other dietary changes and creating its private black schools and culturally-centered curriculum. Finally, the Nation created an economic plan that envisioned a collaborative enterprise built on non-European control. All of these initiatives intended to repair Black people and prepare them for active engagement in the increasingly liberated non-European global community, particularly but not exclusively in Africa.

Since its founding, the Nation has remained oppositional to white supremacy in all institutions. Therefore, it is not surprising that wherever Europe or the United States encountered enemies, the Nation of Islam sought alliances both explicitly and implicitly. For example, Elijah Muhammad and many of his followers found themselves imprisoned for their refusal to participate in World War II. Elijah Muhammad adamantly encouraged his followers to choose jail over war (Essien-Udom 1971). By doing so, the Nation took a pro-Japanese stand against European-American imperialism and white supremacy. Muhammad argued that Black people had no place in a war against other non-Europeans and that Black people, particularly those in the U.S. living under an oppressive racist regime, could not in good conscious fight a war for democracy against fascism and tyranny when they faced the very same challenges at home. In their estimation, World War II was proof of efforts by the U.S. and Europe to define and control other nations in socio-political terms.

In some ways, this stand against World War II is one of the earliest indications of the Nation's internationalism, specifically their position to symbolically stand on the side of other nations against European-American encroachments. The Japanese also likely gained favor among Black Muslims because of their earlier attempts against Western imperialism, particularly during the Russo-Japanese War in 1904. For the NOI it seemed any triumph over Western control and imperialism was seen as a coup for all non-European peoples (Jacob 2017).

Other benchmarks of internationalism, even if viewed as marginal, were most evident in the Nation of Islam's interactions and developing relations between Egypt, Libya and Saudi Arabia. As emissary to the NOI, Malcolm X, traveled to Saudi Arabia and Egypt in 1959. He reported the details of his trip in the Pittsburg Courier, which outlined the success of his travels and the enthusiasm he received from both Africans and Arabs regarding the work of the Nation. That same year, Elijah Muhammad traveled to Cairo and Mecca. During his trip, Muhammad made the Umrah, which is a smaller version of the annual Hajj pilgrimage to Mecca in Saudi Arabia (Essien-Udom 1971). Clearly, the Nation of Islam documented these trips in the black media for two important reasons. First, the Nation attempted to affirm their standing as an authentic and recognized Muslim movement among other established Muslim communities, particularly Saudi Arabia-the fountainhead of Islamic authority-where the presence of the Kaaba guaranteed Saudi Arabia's reputation as the most sacred place in the Muslim world. Having the Nation's leader travel to the so-called Middle East seemed most important in ensuring the authenticity of the NOI as an Islamic entity, given the claims by some orthodox Black American Muslims, like singer Dakota Staton, that the Nation was not a genuine Islamic community. Staton and others asserted that if Muhammad or other NOI followers attempted to enter Mecca, they would be blocked because of their inauthentic practice of Islam. The second reason they documented their travels was to demonstrate to American Muslims and any would-be sympathizers, that the Nation was recognized as part of one of the largest and most powerful religious communities. As the second largest religion in the world, Islam had both the numbers and resources to combat Western and Christian imperialism if needed. This meant that the Nation of Islam was not isolated but part of a welcoming Muslim brotherhood. When Muhammad returned to the U.S from making Umrah, he shared, "The whole world of Islam is behind me" (Lincoln 1961, p. 226). 
Clearly, Muhammad felt that Malcolm X's overseas success and his own trip was enough to cast the Nation as an authentic and important Muslim community within the West and therefore represented an important step towards solidifying their international significance. Lincoln (1961) also argued that, "The Muslim leader [Elijah Muhammad ... had powerful friends abroad to sponsor and receive him and this extended to his followers" (p. 226). Again, Lincoln acknowledged Muhammad's growing significance on the international stage which would help to spread his version of Islam that included black self-determination as a cornerstone of their movement.

Islam, Muhammad observed, was "the black man's religion," and black from this perspective seemed to include his desire for brotherhood and unity of all who were non-European. In Muhammad's estimation, Islam remained a significant factor in liberating Black people and perhaps even all people, not only in the U.S. but throughout the African Diaspora. As such, Elijah Muhammad constructed a unique black identity that was relevant across borders and an identity wherein race and religion intersected, such as in the case of the Black Muslim or "The Asiatic Black Muslim Man." The Nation's concept of the Black Man encompassed the vision of an inherent internationalism, which also represented a historical bond that was born out of Western imperialism.

Consequently, it is not by chance that Elijah Muhammad and the Nation fostered a positive relationship with both Egypt and Libya, both of which represented the intersection of Muslim and African origins that rejected western imperialism and by proxy Christianity. From Muhammad's perspective, non-Europeans or the global racial majority, shared a historical opponent-the West. At some juncture in their histories, they had been conquered, exploited, and, in some cases socioeconomically destroyed at the hands Europeans. From Asia to Africa to the Americas, non-Europeans had experienced disruption and destruction. It was in this ruinous chaos that people found their connectedness, particularly people of African and Asian descent. As an example of Elijah Muhammad's aspirations, in 1958, he penned and forwarded a letter to the African-Asian conference and addressed it to Lt. President Gamal Abdel Nasser, who was attending the conference in Cairo. He wrote:

As Salam Alaikum. Your long-lost Muslim brothers here in America pray that Allah's divine presen[ce]will be felt at this historic African-Asian Conference, and give unity to our efforts for peace and brotherhood. Freedom, justice and equality for all Africans and Asians is of far-reaching importance not only to you of the East, but also to over 17 million of your long lost brothers of African-Asian descent here in the West ... May Allah open and guide the hearts and minds of ... those who are participating in this great conference ... May our sincere desire for universal peace ... bring about the unity and brotherhood among all of our people which we all so eagerly desire. (Muhammad 1958, p. 9)

The African-Asian Cairo Conference delegates included a mix of students, professionals and heads of state. At the conference, an Afro-Asian Solidarity Council was established. Egypt provided space for the council and funding as well. One of the tasks of the council was to "promote Afro-Asian solidarity movements in all countries on the two continents" (Jack 1958, p. 6). The Nation's internationalism was anchored in the most important aspects of black self-determination, namely unity, self-help and economic development, all of which the conference represented. This ethnic-religious solidarity anchored the NOI in the two identities that Muhammad strongly reinforced:

Islam recognize[s] complete equality of Brotherhood; a Muslim is truly the brother of another Believer, regardless of how black the skin or how kinked the hair. He is welcomed with sincere and open arms and recognized by his light-skinned or copper-colored Arab brother. He is also recognized in the same way by his brown or yellow-skinned Japanese, Chinese and Indian brothers. Can you say this for your Christianity ... ? No, your slavemasters' religion does not recognize equality of brotherhood. (Muhammad 1957c, p. 37)

Long before Elijah Muhammad penned this letter of support for President Nasser and the Cairo conference, the Nation of Islam had established ties with the Egyptian government. President Nasser 
came to power in1954 and to international prominence after the Bandung Conference of 1955. At the conference, Nasser advocated a position of nonalignment similar to Ghana's Kwame Nkrumah and Guinea's Sekou Toure. Nasser was also popular because of his efforts to unite Arab countries. For example, in 1958, he united Syria and Egypt, together which formed the United Arab Republic. After seventy-two years of British domination over Egypt, Nasser also successfully worked to liberate Egypt, a triumph that was also well-received in Africa and the Arab world. Lastly, after Israel's attack on Egypt (an attack the U.S. support), Nasser briefly severed ties with the U.S. (Blanga 2015). All of these moves seemingly represented Egypt's commitment to self-determination and thus a strong challenge to the West.

Nasser's work of unification, industrialization, economic recovery and self-determination likely attracted Muhammad to his leadership, as it mirrored similarities with the Nation of Islam's ambitions, and-nation building efforts to operate outside American control. Consequently, in the late 1950s, Muhammad sent two of his children, along with several other University of Islam students, to study Arabic at the Mosque-University of Al-Azhar in Cairo (Essien-Udom 1971). Entrusting young Black American Muslims to Egypt's university helped to not only present model examples of the NOI to Egyptians but also helped to pave the way for an even stronger coalition with this critical African-Muslim regime. These early study-abroad opportunities played an important role in helping to situate Black Muslims as a distinct and important Muslim nation within the United States, one of the most powerful Christian countries in the world. It also allowed the Nation to offer one of the largest Arabic programs in the U.S. during the time (Curtis 2006). Nasser's motivation likely stemmed from his desire to cause some discomfort for Americans and also from a genuine interest in seeing Islam advance in the United States. Later, under Farrakhan's leadership, Egypt would remain an ally of the Nation of Islam but not to the extent it had been under Muhammad. This was likely because of the shift in Egypt's leadership after 1970, as they started to reflect a more pro-American stance.

In terms of other parts of the continent, in the 1960s, the Nation of Islam sent a delegation to Ghana in the wake of its independence from Great Britain. In 1957 the Nation of Islam took out an Ad in the Pittsburgh Courier offering a salute to the newly liberated country (Muslims of America 1957). Part of the Ad read "We are familiar with the bitter taste of servitude thus our aching hearts burst with pride and joy to see our once-enslaved Brothers and Sisters of Ghana getting their priceless independence" (Muslims of America 1957). Although it is not clear just how significant the relationships were between the Nation of Islam and recently-liberated African nations, it is clear that all parties shared a desire for the end of Western imperialism. Nation literature from the period is replete with references to Africa and other parts of the Afro-Asian world, particularly Egypt, Ghana and Tanzania. The Nation sought to connect its work with other non-white nations in their move toward black self-determination. For example, in a column titled Up To Date (1961) the writer stated that Algeria [is] "a nation of people determined to own their own land and govern themselves; Panama [is] a nation of dark men determined to own their own land and govern themselves; [The] United Nations [is] a place of utter confusion ... a Dracula created and supported by West; Syria there is yet a sound to be heard from this land of the black man in the surging path of Islam; and [in] South Vietnam there was a time ... when the nonwhite was in peace."

As informal Nation ambassadors, Black Muslim women and men wrote articles, traveled abroad and provided successful models of what Muslims in America had accomplished, even under racial and religious oppression. Indeed, the Nation's growing international recognition was made possible by Malcolm X, who served as the Nation's national spokesman prior to his suspension in November 1963 and later by Farrakhan, who replaced Malcolm X as spokesman after his final departure from the group in March 1964. Other ministers also contributed to the NOI's international renown, including the heavyweight champion Muhammad Ali. Following in his father's footsteps, Herbert Muhammad also traveled to Africa, Egypt, Jamaica and other countries as part of his official duties as head of the NOI's public relations. Additionally, by documenting her travels and experiences residing in Sudan, Muhammad Speaks, the Nation's official news organ, NOI representative Bayyinah Sharieff also played 
an important role. In fact, travel narratives played an especially important part in helping to spread the Nation of Islam's message and linking members to other African and Asian and Muslim societies. Men and women wrote extensively on the topic of Asian-African relations, their mutual struggle and the desire for coalition-building throughout the African-Asian diaspora. The article titled "Women in Africa Seek Closer Ties with Sisters in America" represents such attitudes and writings. The author of the work writes, "The increasing empathy and understanding between Africans and Afro-Americans is one of the emerging political factors which the West now must contend with. The artificial separation which existed between Negroes and their African brothers maintained by divisive White supremacy, is now being swept aside by the obvious respect both have for the struggles for freedom being waged by the other" (Muhammad 1964).

Outside of Saudi Arabia, Egypt and other countries, Libya had the longest relationship with the Nation of Islam. It is unclear how Elijah Muhammad first made contact with the Libyan leader Muammar al-Qaddafi. Similar to his letter to President Nasser in 1958, Muhammad may have sent Muammar al-Qaddafi some kind of correspondence congratulating him on his successful overthrow of King Idris, his work to unite Arab countries and his strong support of full African independence, particularly North African countries. Though Qaddafi had only gained recognition for his military coup in 1969, by 1972 Elijah Muhammad had successfully obtained a 3 million dollar no-interest loan from the Libyan leader. Previously, no other Black American group has received such tremendous monetary support from inside or outside the U.S., nor has any group since that time outside of Farrakhan's community. The loan was aid to be given to help expand the Nation headquarters in Chicago. In a speech announcing the loan, Qaddafi reportedly indicated "that he supported American Blacks against American arrogance, the white superiority complex" (Muslims Get Loan 1972). Qaddafi's support likely contributed to increased perceptions regarding the Nation of Islam's authenticity, which would serve as an important tool for Muslims and for people of African descent as they collaborated against white supremacy, Christian cultural dominance and European imperialism.

Whether material or symbolic evidence of the Nation's international links included attention from Pakistani Abdul Basit Naeem, who edited the Moslem World \& the U.S.A., the first monthly journal on Islam in the United States. In 1956 and 1957, the journal featured the Nation's efforts, particularly the Muslim school, for instance. In his writings, Abdul Basit Naeem drew correlations between the work of the NOI and called their program the "ultimate solution to the world's cumbersome, persistent and perplexing problems." He also described the Muslim program under the Nation as "the panacea for all ills afflicting humanity" (Naeem 1967). Naeem clearly appreciated the NOI's international significance and he believed that their programs provided the solution to the issues facing the global racial majority. The Nation also received acknowledgements from the Jamaican Prime Minister Michael Manley in 1975 and the hosted various dignitaries from Japan, Kenya and representatives from a number of other countries at their Chicago base.

Under Farrakhan, the Nation reached new international heights. As a result of his leadership, the NOI became the most popular Black Muslim movement in the world. The renewed Nation attempted to maintain the vision and the ties Elijah Muhammad initially established. Farrakhan's message possesses international allure and application not only in the NOI's brand of Islamic religiosity but also in its ability to remain anchored in the most important aspects of black self-determination, black unity, self-help and economic development. "Just four months after the Million Man March in October 1995, Farrakhan took his message abroad in his World Friendship Tour. Visiting "23 nations in 35 days." (Marshall 1996, p. 241). Farrakhan visited places like Sudan, Libya, Nigeria and Iraq. As a result of his growing international status and association with so-called enemies of the U.S., Farrakhan was accused by U.S. State officials as "cavorting with terrorists." While some denounced his travels abroad, especially to places considered adversarial to American democracy, others celebrated his message of black (and to a lesser degree Muslim) unity and atonement (Jones 1996). On his Caribbean tour from Jamaica to Cuba, Farrakhan remarked about the need for a Caribbean coalition, similar to past calls for 
a United Africa. Lastly, Farrakhan collaborated with national and international leaders to create an international economic fund, though unsuccessful.

In terms of the Nation's continued relationship with Muammar al-Qaddaf, Farrakhan's newspaper, Final Call, provided an alternative narrative about the late Libyan leader. From their perspective, Qaddafi was the quintessential embodiment of a Black Muslim with a black-self-determination agenda. He supported black and Muslim liberation struggles around the world, from Palestine to South Africa to America. When Qaddafi visited the U.S. in 2009 for the U.N. General Assembly, Farrakhan remarked that Qaddafi "was on the frontline of many [Black] liberation struggles including ones focused on freeing Mandela, the anti-Apartheid movement in South Africa and the continued Palestinian struggle" (Arinde 2009, p. 32). As he had with Muhammad, Qaddafi certainly provided monetary support to Farrakhan, including a five-million-dollar interest-free loan. Qaddafi welcomed the new NOI members into the Muslim brotherhood as he had in the 1970s. Perhaps his most important role was his work to unite Africa, in addition to the establishment of the African Union. This call to build a United Africa and later Caribbean resonated with NOI members who also hoped to advance a united front among all non-Europeans within the U.S. and on the global stage, as they worked together on different fronts to free the world from white supremacy and imperialism.

\section{Black Power Interventions for a Global Black Audience}

Given the Nation's international ambitions, three of the most popular and portable aspects of the NOI's programs, under Elijah Muhammad and later Minister Farrakhan, included its newspapers (Muhammad Speaks and Final Call), its educational outreach and its economic campaigns. All three agendas prioritized black self-determination, self-help and economic innovation and independence. The Nation newspaper Muhammad Speaks began publication in 1960. Prior to its publication, Elijah Muhammad shared aspects of his theology in major black newspapers, including the Pittsburgh Courier, New York Amsterdam News and Afro-American. Under the weekly editorial "Mr. Muhamad Speaks," Elijah Muhammad touched on the history of Jesus and what Islam offered Black Americans that Christianity could not (Muhammad 1957a, A6 and Muhammad 1957b, B2). Subsequently, Muhammad Speaks also outlined the programs and accomplishments of the NOI. It also maintained a record of white supremacy and its impact both inside and outside the United States. Black media, specifically newspapers, have always played an important role in the black liberation struggle and Muhammad Speaks fit comfortably within this tradition. The Black press provided an alternative to the mainstream media's narrative of Black America. The Final Call newspaper picked up where Muhammad Speaks left off. The Final Call remains one of the few international, independent, outspoken and unbought black nationalist newspapers founded in the 20th century. The paper covers issues that the mainstream media (and even some contemporary Black outlets) neglect and it helps to highlight not only the problems that plague Black people in America but other racially marginalized groups. It also documents their contributions and accomplishments from around the world. In many ways it is a paper that attempts to include the experiences and challenges of the racial global majority, particularly those who remain socially and politically marginalized in the international arena. Like Muhammad Speaks, the Final Call unapologetically covers the abuse of power by the U.S. government and military against less powerful countries such as Iraq, Iran, Afghanistan, Libya and Syria (Baylor 2010). Like its predecessor, Minister Farrakhan's NOI documents the continued assaults instigated by people of European descent such as the illegal murders of Iraq and Libya leaders which left these countries severely unstable. Lastly, the Final Call maintains a close eye on American dealings with Iran and provides a needed account of Israel and its dealing with Palestinians (Damu 2007). Like Muhammad Speaks, the Final Call continues to shine a light on the duplicitous nature of American foreign affairs, while chronicling the Black and Brown struggle against injustice. As an important historical record it continues to remind the global majority of the urgent need to eradicate global white supremacy and Western imperialism. Though established in the U.S., both Muhammad Speaks and Final Call function as powerful symbols of black power and garnered an international readership. 
In terms of education, the Nation of Islam under Elijah Muhammad began by offering three sets of programs, several of which expanded globally. Their education programs included a K-12 school and gender-specific support groups, such as Muslim Girls in Training (MGT) and the Fruit of Islam (FOI). The school system allowed Black Muslims to play a primary role in shaping the kind of education their children would pursue. Their holistic curriculum included language learning, specifically Arabic, beginning as early as the fourth grade, religion, self-defense, calisthenics, writing and history. Studies also centered around curriculum that would bolster careers in STEM, specifically in the areas of engineering, agriculture, mathematics medicine and the sciences (Essien-Udom 1971, pp. 239-41). The University of Islam, later renamed Sister Clara Muhammad Schools in honor of Elijah Muhammad's wife, founder of the school, celebrated the fact that the school emerged as the first and only to offer Black children a universal education that prioritized the necessary skills to become Nation leaders and build lasting institutions. Elijah Muhammad and his followers spent considerable time discussing the mis-education of Black people. Specifically, Muhammad addressed the lack of self-knowledge and the damage inflicted against Black people who attended schools that White people created and controlled. Muhammad believed that the education offered in these environments made Black people even more dependent on Whites who indoctrinated Black people with a lack of desire for true advancement. Muhammad (1965) shared, "Today with all of our white civilized schooling, we have not been taught of our own. They will never teach us of our own" (pp. 48-49). Moreover, "It is knowledge of self that the so-called Negros lack that which keeps them from enjoying freedom, justice and equality. This belongs to them divinely as much as it does to other nations on earth" (Muhammad 1965, p. 31). Free until 1959, the NOI established private Muslim school systems in every major city, including Chicago, Detroit, Philadelphia, New York and Atlanta. The educational plan was also reproduced outside the United States. For example, under the original NOI, Bermuda established a University of Islam. Under Farrakhan's Nation, the London community started a school and in France and several other countries, members held small study groups. As a former Chicago public school teacher and for a time National Director of the University of Islam prior to 1975, Christine Muhammad (Muhammad 1962) observed:

“The social sciences and history books used in our schools are 'primers in white supremacy,' and the longer the child continues in school the more his mind is patterned after his slavemaster and by the time he completes training for his bachelor's or master's or Ph.D. degrees, he is a complete replica of his master and has no desire or incentive to change. Therefore, if we are to ever break away from our masters and the spell they've cast upon us, we must act now and start teaching our pre-school and early school age children ourselves. Let them see black, brown, cream and yellow faces when they open their books. Let them become accustomed early in life to the ideas, that he has something to strive for. Let them realize early that they have a history with meaning and not a meaningless, nebulous something about 'Negro history and how much progress we have made since slavery.' Tell them, with conviction and assurances on your part about their history 'all the way back to Africa, when the white man lived in caves and was a savage, then we won't have to waste time trying to re-educate fools with degrees."

Women of all ages found support, direction and value within the Muslim Girls and Training Program (MGT); meanwhile, the men and boys trained under the Fruit of Islam (FOI). Both groups addressed historical concerns about violence against black bodies, the destruction and deliberate economic instability of Black families, the negative deterioration of black female-male relationships and self-care. In response women directed workshops or classes on grooming, self-defense, nursing, haircare, cooking, children, homecare, budgeting, mathematics, writing, sewing and other topics. For men, courses included self-defense, fatherhood, marriage, grooming, mathematics, writing, work/entrepreneurship and other topics. Like the schools the MGT and FOI programs also migrated to other countries, including Bermuda and England. This is likely because the NOI regarded many of these skills as universal and thus hoped to address similar issues faced by those who experienced 
marginalization and economic disadvantage in any country. This was especially the case in places like the United Kingdom, where police brutality, unemployment, mis-education and discrimination plagued Black people (Muhammad 1997). Though Minister Farrakhan reinstated both these groups the objectives, workshops and classes change to some degree.

The last element of the NOI program to garner an international audience included the economic blueprint for the group. Even today, there remain several elements of the original Nation's economic legacy: (1) fund raising for local and national communities; (2) building domestic and international enterprises; and (3) establishing banks and savings programs. Fundraising efforts assumed several forms, bazaars, selling dinners, membership dues, donations, fashion shows and other structures. The national office received a share of the funds and the remaining portions were used to meet local needs, such as building maintenance, utility bills and other essentials. Other promising ventures included the Nation's printing press, which published the newspaper and other materials, including Elijah Muhammad's classic Message to the Black Man in America, The Fall of America, How to Eat to/live Vol $1 \& 2$ and other books. Clothing factories in Chicago, Philadelphia and New York also proved important. The H\&G Whiting import enterprise also spoke to their international aspirations. In 1973, Elijah Muhammad's NOI negotiated with Peru to import Whiting Fish. This initiative added to their heathy food initiative and included restaurants and grocery stores that provided healthy options in food insecure neighborhoods. The Nation provided a much-needed resource to poor communities of color. The initial ports included Los Angeles, Mobile AL and Savanah, GA. In 1974, the Nation expanded delivery from Peru to New York ports (Johnson 1974). What made the H\&G Whiting initiative significant is not only that it was the first of its kind by a black American movement but that it sought a direct trade relationship between Black Americans and other non-European nations, free from the domination of White mediators. By creating an economic pipeline that directly and mutually benefitted non-Europeans, Black American communities and Peru, this trade allowed the Nation to operate literally as a 'nation within a nation.' However, H\&G Whiting was short-lived. The most glaring reason for its decline was likely W.D. Mohammed's desire for assimilation and a move toward American patriotism, thereby doing away with programs that promoted the intersection of black power and Islam. Other factors also likely included pressure placed on Muslim members, particularly men, to sell the fish. In some cases, in order to meet quotas, set by each temple, some men used their earnings to purchase the fish they could not sell. The United States federal government may have imposed significant taxes and other fees to undermine their enterprising efforts, as well. Lastly, the venture may have proven to be costlier than expected. Whatever the reasons, for a brief moment, the Nation of Islam "had a place in the sun" a moment where their vision of economic industry by and for Black people had actually come to fruition and helped to raise the bar of their aspirations as an international economic force. (Muhammad 1965, p. 175).

\section{Conclusions (Effectiveness of NOI Internationalism)}

It is difficult to assess the Nation of Islam's achievements in terms of its internationalism. If success can be based on persistence of NOI theology, temples, study groups, businesses flying the NOI flag and schools, the Nation proved effective in terms of reaching beyond the borders of the United States. In the U.S., the NOI successes are more explicit, though still generally overlooked by scholars. Clearly, the U.S. saw the greatest benefits of the Muslim movement. The fact that, one, Islam is the fastest growing religion in the U.S. and, two, Black people are the great majority of converts in the country speaks to the Nation's influence (Dannin 2002; Durand 1996, Lipka and Hackett 2019). According to historian Dannin (2002) Black people in the U.S. make up nearly $90 \%$ of converts to Islam. In addition, though the numbers are small, Black Muslims schools peppered throughout the country remain important alternatives to other religious institutions and public schools. In most cases, outside of some independent black schools, black Muslim schools, though few, remain the only line of defense against the mis-education of young Black people. Globally, the Nation's value is evident in the few schools, study groups, MGT and FOI units that exist abroad, mainly in Bermuda and London. The impact of 
food and dress (NOI distinct uniforms) is also evident. But more importantly, the Nation's message of black power through religious reinvention persists. By way of the Nation, Black people have received an opportunity to cast themselves in a more progressive narrative that has afforded many a better life, free from many of the remnants of chattel slavery, particularly in the case of religion. The Nation provides an alternate life by and for people of African descent. As taught by the NOI, Islam means Freedom, Justice and Equality-the direct opposite of what Christianity has been historically for the Black people in the U.S. and even on the international stage. The NOI equates Christianity to "Slavery Suffering and Death." Their critique of Christianity has had international implications-it was cultural but also political. The NOI saw themselves allied with both Muslims, Africans and other non-Europeans against white supremacy and Western imperialism.

Under Minister Louis Farrakhan, the NOI agenda continues to be linked to the African Diaspora. The new Nation has successfully re-established followings all over the world, including Europe, Dominican Republic and parts of the Caribbean. As leader of the Nation, Farrakhan has convened with various heads of state, including Mugabe, the former President of Zimbabwe, the late Saddam Hussein and Muammar Qaddafi. In the 1990s, he effectively secured over a million dollars from Libya in order to help build up his enterprises. Farrakhan's NOI reestablished businesses and schools in the U.S. and abroad. The Nation of Islam continues to link the 21st century African-American struggle for human rights with the broader Muslim struggles of the Palestinians, Syrians, Iraqis and the like, fighting against Western Judeo-Christian imperialism and European-American capitalist interests and white supremacy. The NOI newspaper has continued to cover the nearly twenty-year war in Iraq and Afghanistan. It continues to critique the United States for what it sees as "its real" intentions of capitalistic imperialism and a whole host of war crimes that continue unabated and unredressed (Walker 2005, pp. 542-44).

For nearly ninety years, the Nation has provided important interventions and an assessment of persistent racial, political, social and economic inequality, American and European government intrusion into governments run by non-Europeans. They have remained a constant force for addressing police brutality, educational divestment and more. Both the original and, under Minister Farrakhan, the new Nation of Islam remains one of the most under-acknowledged yet consistent and important organizations that has exhibited tremendous international dimensions. Most importantly, its impact emerged out of the twentieth-century spirit of "Black Power.'

Funding: This research received no external funding.

Conflicts of Interest: The author declares no conflict of interest.

\section{References}

Arinde, Nayaba. 2009. Libya's Qadhafi and Farrakhan in NYC Next Week. The New Amsterdam News. September 17-23. Available online: http://amsterdamnews.com/news/2011/apr/12/libyas-qadhafi-and-farrakhan-in-nycnext-week/ (accessed on 18 March 2015).

Baylor, Leroy. 2010. Farrakhan Uses Saviour's Day to Address the Believers and Has a Message for President Obama. The New York Amsterdam News. March 4. Available online: https://search-ebscohost-com.proxy. library.ohio.edu/login.aspx?direct=true\&db=b7h\&AN=48839989\&site=eds-live\&scope=site (accessed on 18 March 2015).

Blanga, Yehuda U. 2015. Nasser's Dilemma: Egypt's Relations with the United States and Israel, 1967-1969. Middle Eastern Studies 51: 301-26. [CrossRef]

Curtis, Edward E. 2006. Black Muslim Religion in the Nation of Islam, 1960-1975. Chapel Hill: The University of North Carolina Press.

Damu, Jean. 2007. Rounding up undocumented workers: Reflection on the ICE Raids. Final Call, October 2. Dannin, Robert. 2002. Black Pilgrimage to Islam. New York: Oxford University Press. 
Durand, Maria F. 1996. African-American Converts Help Make Islam Fastest Growing Religion in U.S. San Antonio Express-News. February 17. Available online: https://infoweb-newsbank-com.proxy.library.ohio.edu/apps/ news/openurl?ctx_ver=z39.88-2004\&rft_id=info\%3Asid/infoweb.newsbank.com\&svc_dat=AWNB\&req_ dat=82BAEF1199504D54B81EDE1B13626EB5\&rft_val_format=info\%3Aofi/fmt\%3Akev\%3Amtx\%3Actx\& rft_dat=document_id\%3Anews\%252F0EB03D62D928402C (accessed on 17 June 2018).

Essien-Udom, Essien Udosen. 1971. Black Nationalism: A Search for an Identity in America. Chicago: University of Chicago Press.

Jacob, Frank. 2017. The Nation of Islam and Japanese Imperial Ambitions. In New Perspectives on the Nation of Islam. Edited by Dawn Marie Gibson and Herbert Berg. New York: Routledge, pp. 118-32.

Jack, Homer A. 1958. The Cairo Conference. Africa Today 5: 3-9.

Johnson, Rudy. 1974. Black Muslims Turn to Imports. New York Times. June 13. Available online: https://www.nytimes. com/1974/06/13/archives/black-muslims-turn-to-imports-peruvian-fish-shipped-here-for.html (accessed on 18 June 2019).

Jones, Charisse. 1996. Farrakhan Defends His World Tour Before a Receptive Crowd in Brooklyn. New York Times. May 14. Available online: http://www.nytimes.com/1996/05/14/nyregion/farrakhan-defends-his-world-tourbefore-a-receptive-crowd-in-brooklyn.html (accessed on 1 February 2018).

Joseph, Peniel E. 2006. The Black Power Movement: Rethinking the Civil Rights-Black Power Era. New York: Routledge. Lincoln, Charles Eric. 1961. The Black Muslims in America. Boston: Beacon Press.

Lipka, Michael, and Conrad Hackett. 2019. Why Muslims Are the Fastest Growing Religious Group; Washington, DC: Pew Research Center. Available online: https://www.pewresearch.org/fact-tank/2017/04/06/why-muslimsare-the-worlds-fastest-growing-religious-group/ (accessed on 17 June 2019).

Marshall, A. 1996. Louis Farrakhan: Made in America. Orlando: BSB Publishing.

Muhammad, Elijah. 1957a. Jesus' History from the Mouth of Allah (God). Pittsburg Courier, August 10, A6.

Muhammad, Elijah. 1957b. The American So-Called Negros' Salvation is in Islam, the Only True Religion of God. Pittsburg Courier, May 18, B2.

Muhammad, Elijah. 1957c. The Supreme Wisdom. Atlanta: M.E.M.P.S, vol. 1.

Muhammad, Elijah. 1958. Mister Muhammad's Message the African-Asian Conference. Pittsburgh Courier, January 18. Muhammad, Christine. 1962. Self Help or Oblivion for the Negro. Muhammad Speaks.

Muhammad, Elijah. 1965. Message to the Blackman in America. Newport News: United Brothers Communication Systems. Muhammad, Harriett. 1964. Women in Africa Seek Closer Ties with Sisters in America. Muhammad Speaks, July.

Muhammad, Rosalind. 1997. The Rise of the Nation of Islam in London. Final Call. May 5. Available online: http://www.finalcall.com/perspectives/noi-london5-6-97.html (accessed on 2 February 2019).

Muslims Get Loan. 1972. Milwaukee Star. XII: p. 3. June 22. Available online: https://infoweb-newsbankcom.proxy. library.ohio.edu/apps/readex/doc?p=EANAAA\&docref=image/v2:12A7AE31A7B3CA6B@EANAAA12B9CCCFD4827530@2441491-12B9CCD006419FA0@4-12B9CCD1C239E688@Muslims+Get+Loan (accessed on 3 April 2019).

Naeem, Abdul Basit. 1967. Sees ‘Divine Purpose in the Trials, Humiliation, Suffering of Muslims. Muhammad Speaks, July 7.

Ogbar, Jeffrey OG. 2005. Black Power: Radical Politics and African American Identity. Baltimore: Johns Hopkins University Press.

Up To Date. 1961. Muhammad Speaks. December. Available online: https://issuu.com/muhammadspeaks/docs/ december-1961 (accessed on 26 June 2019).

Walker, Dennis. 2005. Islam and the Search for African American Nationhood: Elijah Muhammad, Louis Farrakhan and the Nation of Islam. Atlanta: Clarity Press.

X, Malcolm. 1959. Arabs Send Warm Greetings to 'Our Brother' Of Color in the U.S.A. Pittsburgh Courier, August 15.

(C) 2019 by the author. Licensee MDPI, Basel, Switzerland. This article is an open access article distributed under the terms and conditions of the Creative Commons Attribution (CC BY) license (http://creativecommons.org/licenses/by/4.0/). 